\title{
Market Integration of Sesame Seeds in South Asia (Research Article)
}

\author{
Güney Asya'da Susam Tohumu Marketi Bütünleşmesi
}

Doi: 10.29023/alanyaakademik.646546

\section{S. SADIQ}

Department of Agricultural Economics and Extension, FUD, Dutse, Nigeria

sadiqsanusi30@gmail.com

Orcid No: 0000-0003-4336-5723

\section{P. SINGH}

Department of Agricultural Economics, SKRAU, Bikaner, India

Orcid No: 0000-0002-1886-5956

\section{M. AHMAD}

Department of Agricultural Economics, BUK, Kano, Nigeria

Orcid No: 0000-0003-4565-0683

How to cite this article: Sadiq, M.S. Singh I.P. \& Ahmad, M.M. (2020).Market Integration of Sesame Seeds in South Asia. Alanya Academic Review, 4(1), Page No. 143-155.

\begin{tabular}{ll} 
& ABSTRACT \\
\cline { 2 - 3 } Keywords & $\begin{array}{l}\text { The present research empirically determined the spatial price linkage of } \\
\text { South-Asia exporting sesame seeds markets with the importing market using } \\
\text { Price, Integration, } \\
\text { Market, Sesame, } \\
\text { South-Asia }\end{array}$ \\
techniques used to achieve the stated objective were descriptive and \\
Received: 13.12.2019 \\
Accepted: 24.01 .2020 markets were not autarkic as price information was efficiently transmitted \\
$\begin{array}{l}\text { across the geographical far apart markets. Furthermore, the traders } \\
\text { effectively responded to price innovation or shock in order to maintain price } \\
\text { equilibrium in their respective markets. Evidence showed that hike in low- } \\
\text { quality prices would be relatively less reflected in Bangladesh and Pakistan } \\
\text { markets. Thus, the study recommended network design for sesame } \\
\text { producer's markets across the region at an almost equal distance from each } \\
\text { other to enhance integration and better price communication among the } \\
\text { exporting and importing economies. }\end{array}$ \\
\hline
\end{tabular}

\section{INTRODUCTION}

Efficient functioning ofmarkets is an essential prerequisite forsound marketing systems that provide remunerative prices to the farmers/producersas well as provide goods at reasonable prices tothe innumerable consumers (Singh, 2014). One of the common indicators ofan efficient functioning of markets is the existence of a highdegree of integration between them (Waniet al., 2015). The existence of integration inthe markets influences the conduct of the firms in the marketsand consequently the marketing efficiency (Praveen and Inbasekar, 2015). 
The analysis of price movementof a commodity in the corresponding and linked marketshelps in judging the extent of efficiency of the marketingsystem in the region for the selected crops (Singh, 2014). The ultimateobjective of planners and policymakers in the field ofagriculture marketing is to develop efficient markets for theagricultural product produced by the farmers of a region.If farmers can get remunerative price for their produced commodity, they will have the tempo of incentive for increased production.

The present structure of the agriculturalmarketing system prevailing in South-Asia may not be conducive for improving marketingefficiency of sesame seeds. Poor marketing infrastructures and paucity of information dissemination act as barriersfor better market integration of sesame product in Asia. Price signals transmitted by non-integratedmarkets would misleadproducers' on marketing decisions, thus resulting in inefficientcommodity movement.

Considering the importance of the information evolving out of market integrationstudies, an attempt was made to discern the status of market integration among the South-Asia sesame seed exporting economies and the importing global economy. The broad objective of the research was to determine the market integration of sesame exporting and importing economies, while the specific objectives were to determine the extent and degree of spatial price integration; to predict the future sesame seed prices; and, to determine price volatility of sesame seeds in the selected markets.

\section{RESEARCH METHODOLOGY}

Annual sesame producer's price series data for exporting economies: India (ISM), Pakistan (PSM) and Bangladesh (BSM); and importing economy viz. China (CSM) spanning from 1991 to 2015 sourced from FAO database were used. The data analysis was performed using descriptive and inferential statistics. The first and second objectives were achieved using the unit root tests, Johansen cointegration test and Vector Autoregressive model (VECM); and, the last objective was achieved using the GARCH model.

\section{Empirical model}

\section{Augmented Dickey-Fuller test}

Following Sadiq et al. (2017) the autoregressive formulation of the ADF test with a trend term is given below:

$$
\Delta P_{t}=\alpha+P_{t-1}+\sum_{j=2}^{i t} \beta_{i} \Delta P_{i t-j+t}+\varepsilon
$$

Where, $P_{\text {it }}$ is the price in market iat the time $t, \alpha_{\text {and }} \Delta P_{i t}\left(P_{\text {it }}-P_{t-1}\right)$ is the intercept or trend term.

2. Johansen's co-integration test

Following Johansen (1988) the multivariate formulation is specified below:

So that

$$
P_{t}=A_{1} P_{t-1}+\varepsilon_{t}
$$

$$
\begin{gathered}
\Delta P_{t}=A_{1} P_{t-1}-P_{t-1}+\varepsilon_{t} \\
P_{t}=\left(A_{1}-1\right) P_{t-1}+\varepsilon_{t} \\
\Delta P_{t}=\prod P_{t-1}+\varepsilon_{t}
\end{gathered}
$$

Where, $P_{t}$ and $\varepsilon_{t}$ are $(n \times 1)$ vectors; $A_{t}$ is an $(n \times n)$ matrix of parameters; $I$ is an $(n \times n)$ identity matrix, and $\prod$ is the $\left(A_{1}-1\right)$ matrix. 
Using the estimates of the characteristic roots, the tests for the number of characteristic roots that are insignificantly different from unity were conducted using the following statistics:

$$
\begin{gathered}
\lambda_{\text {trace }}=-T \sum_{i=r+1}^{n} \ln \left(1-\lambda_{i}\right) \\
\lambda_{\text {max }}=-T \ln \left(1-\lambda_{i}+1\right)
\end{gathered}
$$

Where, $\lambda_{i}$ denotes the estimated values of the characteristic roots (Eigen-values) obtained from the estimated $\prod$ matrix, and $T$ is the number of usable observations.

\section{Granger causality test}

Following Granger (1969) the model used to check whether market $P_{1}$ Granger causes market $P_{2}$ or vice-versa is given below:

$$
P_{t}=\alpha+\sum_{i=1}^{n}\left(\emptyset P_{1 t-i}+\delta_{i} P_{2 t-i}\right)+\varepsilon_{i}
$$

A simple test of the joint significance of $\delta_{i \mathrm{i}}$ was used to check the Granger causality i.e.

$$
H_{0}:=\delta_{1}=\delta_{2}=\ldots \ldots . \delta_{n}=0 \text {. }
$$

\section{Vector error correction model (VECM)}

The VECM explains the difference in $y_{t}$ and $y_{t-1}$ (i.e. $\Delta y_{t}$ ) and it is shown below (Sadiq $e t$ al., 2016a; Sadiqet al., 2016b):

$$
\Delta \gamma_{t}=\alpha+\mu\left(\gamma_{t-1}-\beta_{x t-1}\right)+\sum_{i=0}^{i=t} \delta_{i} \Delta x_{t-1}+\sum_{i=1}^{i=t} \gamma_{i} \Delta \gamma_{t-1}
$$

It includes the lagged differences in both $x$ and $y$, which have a more immediate impact on the value of $\Delta \gamma_{t}$.

\section{Impulse response functions}

The generalized impulse response function (GIRF) in the case of an arbitrary current shock $(\delta)$ and history $\left(\omega_{t-1}\right)$ is specified below (Rahman and Shahbaz, 2013; Beag and Singla, 2014) :

$$
\operatorname{GIRF}_{Y}\left(h, \delta, \omega_{t-1}\right)=E\left[Y_{t}+h \| \delta, \omega_{t-1}\right]-E\left[Y_{t-1} \| \omega_{t-1}\right]
$$

\section{Forecasting accuracy}

For measuring the accuracy in fitted time series model, mean absolute prediction error (MAPE), relative mean square prediction error (RMSPE), relative mean absolute prediction error (RMAPE) (Paul, 2014), Theil's U statistic and $\mathrm{R}^{2}$ were computed using the following formulae:

$$
\begin{gathered}
\text { MAPE }=1 / T \sum_{i=1}^{5}\left(A_{t-1}-F_{t-1}\right) \\
\text { RMPSE }=1 / T \sum_{i=1}^{5}\left(A_{t-1}-F_{t-1}\right)^{2} / A_{t-1} \\
\text { RMAPE }=1 / T \sum_{i=1}^{5}\left(A_{t-1}-F_{t-1}\right) / A_{t-1} \times 100 \\
U=\sqrt{\frac{\sum_{t=1}^{n-1} \frac{\left(P_{t+1}-Y_{t+1}\right)^{2}}{Y_{t}}}{\sum_{t=1}^{n-1} \frac{\left(Y_{t+1}-Y_{t}\right)^{2}}{Y_{t}}}} \\
R^{2}=1-\frac{\sum_{i=1}^{n}\left(A_{t i}-F_{t i}\right)}{\sum_{i=1}^{n}\left(A_{t i}\right)}
\end{gathered}
$$

Where, $R^{2}=$ coefficient of multiple determination, $A_{t}=$ Actual value; $F_{t}=$ Future value, and $\mathrm{T}=$ time period 


\section{GARCH model}

The representation of the $\operatorname{GARCH}(p, q)$ is given as:

$$
Y_{t}=\alpha+\beta_{1} Y_{t-1}+\beta_{2} Y_{t-2}+\varepsilon_{i} \text { (Autoregressive process) }
$$

And the variance of random error is:

$$
\begin{gathered}
\sigma_{t}^{2}=\lambda_{0}+\lambda_{1} \mu_{t-1}^{2}+\lambda_{2} \sigma_{t-1}^{2} \\
\sigma_{t}^{2}=\omega+\sum_{i=1}^{p} \beta_{i} \sigma_{t-i}^{2}+\sum_{j=1}^{q} \alpha_{i} \varepsilon_{t-i}^{2}
\end{gathered}
$$

Where $Y_{t}$ is the price in the $i^{\text {th }}$ period of the $i^{\text {th }}$ market, $p$ is the order of the GARCH term and $q$ isthe order of the ARCH term. The sum of ARCH and GARCH $(\alpha+\beta)$ gives the degree of persistence of volatility in the series. The closer is the sum to 1 ; the greater is the tendency ofvolatility to persist for a longer time. If the sum exceeds 1 , it is indicative of an explosive series with a tendencyto meander away from the mean value.

\section{RESULTS AND DISCUSSION}

\subsection{Summary Statistics of the Selected Sesame Seeds Market}

The results showed the sesame seeds prices of the exporting economies to be stable while that of the importing economy to be unstable. Furthermore, the exporting markets with lowest and highest prices were Bangladesh and Pakistan respectively. For the overall, the importing economy (China) had the highest sesame seeds price among the selected markets. The prices of sesame seeds for all the selected markets were positively skewed and this is reasonable since the product inventories cannot be negative, which places a positive skewness bias in the data. Floor prices tend to introduce positive skewness while ceiling prices tend to promote negative skewness. Therefore, from a practical perspective, the presence of positive skewness can help policy design in that positive price asymmetry implies that traders can be quite confident in establishing a minimum price level. Excess kurtosis was not observed as shown by the tails of the distribution which were not thicker than the normal (kurtosis coefficient of less than 3), thus indicating that none of the selected markets exhibited extreme price values.

Table 1. Summary statistics of sesame prices for the selected markets

\begin{tabular}{|l|l|l|l|l|l|l|c|}
\hline Markets & Mean & Min & Max & SD & CV & Skewness & Kurtosis \\
\hline BSM & 387.20 & 223.60 & 633.70 & 129.80 & 0.33521 & 0.72011 & -0.84380 \\
\hline ISM & 557.72 & 402.20 & 782.10 & 113.15 & 0.20288 & 0.45002 & -0.90771 \\
\hline PSM & 660.56 & 488.90 & 919.60 & 91.168 & 0.13802 & 0.98178 & 1.8386 \\
\hline CSM & 1108.70 & 311.40 & 2584.80 & 745.81 & 0.67271 & 0.87499 & -0.72643 \\
\hline
\end{tabular}

\subsection{Lag Selection Criteria}

The results showed that the appropriate length of lag for truncation was lag four as shown by the selection criteria viz. Akaike information criterion (AIC), Schwarz Bayesian information criterion (SBIC) and Hannan-Quinn information criterion (HQC) (Table 2). The inclusion of the chosen lag length will make the model residuals to be pure white noise and also give parsimonious interpretable results. 
Table 2. Lag selection criteria

\begin{tabular}{|l|l|l|l|}
\hline Lag(s) & AIC & BIC & HQC \\
\hline 1 & 47.70 & 48.49 & 47.87 \\
\hline 2 & 46.46 & 48.05 & 46.81 \\
\hline 3 & 45.95 & 48.33 & 46.46 \\
\hline 4 & $40.85^{*}$ & $44.04^{*}$ & $41.54^{*}$ \\
\hline
\end{tabular}

Note: $*$ denote lag length selected by a criterion

\subsection{Unit Root Tests}

The ADF unit root test showed that all the price series were stationary at level as indicated by their respective tau-statistics which were not different from zero at 5\% probability level. But after first difference, all the price series became stationary as indicated by their respective tau-statistics which were different from zero at 5\% risk level. Furthermore, the ADF-GLS unit root test indicated the validity and robustness of the ADF tau-estimates for the price series as evidenced by their respective tau-statistics which were greater and lower than the critical value at level and first difference respectively. Therefore, it can be inferred that the price series are integrated of order one i.e. I(1). With the proof that all the price series are integrated of order one, the multivariate cointegration test was applied to examine the possibility of long-run association (Table 3).

Table 3. ADF unit root test

\begin{tabular}{|l|l|l|l|l|l|}
\hline \multirow{2}{*}{ Market } & \multirow{2}{*}{ Stage } & ADF & ADF-GLS \\
\cline { 3 - 6 } & & $\boldsymbol{t}$ - stat & -value & $\boldsymbol{t}$ - stat & $\boldsymbol{t}$ - critical \\
\hline \multirow{3}{*}{ BSM } & Level & -0.15079 & 0.9325 & -1.32995 & -3.19 \\
\cline { 2 - 6 } & $\mathbf{1}^{\text {st }} \Delta$ & $-4.09892^{* *}$ & 0.0046 & $-4.44421^{* *}$ & -3.19 \\
\hline \multirow{3}{*}{ ISM } & Level & -0.30601 & 0.9218 & -0.58510 & 0.4642 \\
\cline { 2 - 6 } & $\mathbf{1}^{\text {st }} \Delta$ & $-6.01669^{* *}$ & $1.09 \mathrm{e}-07$ & $-4.24070^{* *}$ & $2.35 \mathrm{e}-05$ \\
\hline \multirow{3}{*}{ PSM } & Level & -2.85899 & 0.1761 & -3.10334 & -3.19 \\
\cline { 2 - 6 } & $\mathbf{1}^{\text {st }} \Delta$ & $-3.73597^{* *}$ & 0.0200 & $-4.72773^{* *}$ & -3.19 \\
\hline CSM & Level & -1.21852 & 0.9059 & -1.17545 & -3.19 \\
\cline { 2 - 6 } & $\mathbf{1}^{\text {st }} \Delta$ & $-6.79163^{* *}$ & $6.31 \mathrm{e}-05$ & $-7.10636^{* *}$ & -3.19 \\
\hline
\end{tabular}

Note: $\Delta$ and $* *$ indicate first difference and rejection of null hypothesis at $5 \%$ probability level respectively.

\subsection{Extent of Price Integration}

Empirical evidence showed the existence of effective and efficient price transmission as indicated by cointegration of the vectors at rank for both the trace and max test statistics (Table 4a). This means that prices of sesame among the selected markets move together in the long-run i.e. there is a perfect flow of price information within the horizon of the exporting and importing economies. Furthermore, it implies that the four selected sesame markets shared one stochastic trend with none existence of an independent market in the region. Therefore, it can be inferred that the law of one price (LOP) hold between these markets i.e. the price differential between two markets is equal to the cost of transfer. In addition, the sesame markets in the region are efficiently integrated as the collusive activities of the oligopolistic intermediaries, monopolistic buyers behavior in price fixing on the auction floor and the local powers exercised by the traders are been minimized due to proper market 
infrastructure, ICT, articulated agricultural export measures and efficient and functional commodity exchange markets in the region.

The presence of one stochastic for all the four selected markets implies the likelihood of pairwise co-integration of the prices. The pair-wise co-integration results showed that LOP did not hold between the market pairs (Table 4b). However, there is the possibility of these market pairs to be integrated if considered at moderate to high lag levels.

Table 4a. Multivariate co-integration result

\begin{tabular}{|l|l|l|l|l|l|l|}
\hline $\mathbf{H}_{\mathbf{0}}$ & $\mathbf{H}_{\mathbf{1}}$ & Eigen value & Trace test & P-value & Lmax test & P-value \\
\hline $\mathrm{r}=0$ & $\mathrm{r} \geq 1$ & 0.99997 & 313.50 & 0.0000 & 218.30 & 0.0000 \\
\hline $\mathrm{r} \leq 1$ & $\mathrm{r} \geq 2$ & 0.93678 & 95.199 & 0.0000 & 57.983 & 0.0000 \\
\hline $\mathrm{r} \leq 2$ & $\mathrm{r} \geq 3$ & 0.78262 & 37.216 & 0.0001 & 32.049 & 0.0000 \\
\hline $\mathrm{r} \leq 3$ & $\mathrm{r}=4$ & 0.21814 & $5.1677 * *$ & 0.2752 & $5.1677 * *$ & 0.2746 \\
\hline
\end{tabular}

Note: $* *$ denotes rejection of the null hypothesis at 5 percent level of significance

Table 4b. Pair-wise co-integration result

\begin{tabular}{|c|c|c|c|c|c|c|c|}
\hline Markets & $\mathbf{H}_{0}$ & $\mathbf{H}_{1}$ & Trace test & P-value & Lmax test & P-value & $\mathbf{C E}$ \\
\hline \multirow[t]{2}{*}{ BSM-ISM } & $r=0$ & $r \geq 1$ & 2.9017 & 0.8472 & 2.8998 & 0.7963 & \multirow[t]{2}{*}{ None } \\
\hline & $\mathrm{r} \leq 1$ & $r \geq 2$ & 0.0019 & 0.9836 & 0.0019 & 0.9812 & \\
\hline \multirow[t]{2}{*}{ BSM-PSM } & $\mathrm{r}=0$ & $\mathrm{r} \geq 1$ & 3.0584 & 0.8282 & 2.4209 & 0.8612 & \multirow[t]{2}{*}{ None } \\
\hline & $\mathrm{r} \leq 1$ & $r \geq 2$ & 0.6375 & 0.4886 & 0.6375 & 0.4824 & \\
\hline \multirow[t]{2}{*}{ BSM-CSM } & $\mathrm{r}=0$ & $r \geq 1$ & 6.5402 & 0.3745 & 5.6479 & 0.3993 & \multirow[t]{2}{*}{ None } \\
\hline & $\mathrm{r} \leq 1$ & $r \geq 2$ & 0.8923 & 0.4004 & 0.8923 & 0.3962 & \\
\hline \multirow[t]{2}{*}{ ISM-PSM } & $\mathrm{r}=0$ & $\mathrm{r} \geq 1$ & 3.6392 & 0.7527 & 3.6232 & 0.6884 & \multirow[t]{2}{*}{ None } \\
\hline & $\mathrm{r} \leq 1$ & $\mathrm{r} \geq 2$ & 0.0161 & 0.9395 & 0.0161 & 0.9339 & \\
\hline \multirow[t]{2}{*}{ ISM-CSM } & $r=0$ & $r \geq 1$ & 2.3175 & 0.9101 & 2.1996 & 0.8882 & \multirow[t]{2}{*}{ None } \\
\hline & $\mathrm{r} \leq 1$ & $r \geq 2$ & 0.1179 & 0.7989 & 0.1179 & 0.7897 & \\
\hline \multirow[t]{2}{*}{ PSM-CSM } & $\mathrm{r}=0$ & $\mathrm{r} \geq 1$ & 2.2576 & 0.9158 & 1.5010 & 0.9561 & \multirow[t]{2}{*}{ None } \\
\hline & $\mathrm{r} \leq 1$ & $\mathrm{r} \geq 2$ & 0.7567 & 0.4444 & 0.7567 & 0.4392 & \\
\hline
\end{tabular}

Note: $* *$ denotes rejection of the null hypothesis at 5 percent level of significance CE- Cointegration equation

\subsection{Degree of Market Integration}

A cursory review of the results showed that a price shocks in all the selected markets with the exception of India market that induces price deviations from their respective equilibrium level as indicated by the significance of their attractor coefficients wouldinduce the traders in these markets to respond to the shocks in a way that the priceswould converge toward their equilibrium value (Table 5). The speed at which BSM, PSM and CSM will correct its previous deviation from the equilibrium due to short-run shocks would be $12.4 \%, 47.8 \%$ and $64.1 \%$ respectively; and the approximate time required to re-establish equilibrium would be 1.8, 5.7 and 7.7 months respectively. The flow of information is high in BSM, moderate in PSM and low in the importing market. Hence, BSM is more efficient than PSM in terms of reaction to price news, while the PSM, in turn, is more efficient than CSM in reacting to price news. Based on the foregone discussion, it can be suggested that even though the markets are integrated, there is disequilibrium in the short-run due to the priceadjustments across the 
markets which did not happen instantaneously orsimultaneously.Furthermore,there are delays in the short-run price transmission of these markets as their respective coefficientsof the lagged price differences were different from zero at $10 \%$ degree of freedom. However, further changes in the subsequent periods (lagged 3) for Indian sesame price would help it to achieve equilibrium in the long-run.

\subsection{Direction of Price Formation}

According to Ghafoor et al.(2009), the direction of price formation between the market pair and related spatial arbitrage, i.e. physical movement of the commodity to adjust theprice differences is shown by Granger causality. A perusal of the Table showed market pair viz. BSM-CSM to have bidirectional causality; market pairs'viz. BSM-ISM, BSM-PSM, CSMISM and CSM-PSM to have unilateral causalities while market pair viz. ISM-PSM did not have a causal relationship as indicated by the f-statistics for the first two former which were different from zero at $5 \%$ probability level and the later whose f-statistics were not different from zero at 5\% probability level respectively (Table 6). For the market pair with bidirectional causality, it implies that the former market granger cause price formation in the latter market, likewise the latter market granger cause price formation in the former market i.e. there exist feed-forward and feed-backward relationship between the markets in pair in sesame price formation. In the case of market pairs with unilateral causality, it means that only the lagged of the former in the pair contain useful information in predicting the future price of the latter. However, for the market pairs with none causality, it means that neither the former nor the latter in the pair Granger cause price formation in each direction. Therefore, it can be inferred that the market pair BSM-CSM exhibited strong endogeneity but weak exogenity in pair with other selected markets. However, strong exogenity was observed between the price pair of ISM-PSM, justifying the effect of external influence in determining the direction of price formation in these markets. The dominant influence of BSM in the South-Asia region may be attributed to its quick emergence with an adequate supply of sesame product in the global sesame markets; while the dominant role of CSM may be due to its importing position to meet its high industrial demand. However, the weak influence of ISM and PSM may be due to the possibility of exploring other fast-emerging importing economies in the world with high industrial demand for sesame commodity.

Table 6. Horizontal pair-wiseGranger causality test results

\begin{tabular}{|c|c|c|c|c|}
\hline Null hypothesis & F-stat & $\mathrm{P}<0.05$ & Granger cause & Direction \\
\hline \multirow{2}{*}{$B S M \leftrightarrow I S M$} & $87.53 * *$ & 0.0019 & Yes & \multirow[t]{2}{*}{ Unidirectional } \\
\hline & 2.835 & 0.2092 & No & \\
\hline \multirow{2}{*}{$B S M \leftrightarrow P S M$} & $78.81 * *$ & 0.0023 & Yes & \multirow[t]{2}{*}{ Unidirectional } \\
\hline & 7.822 & 0.0613 & No & \\
\hline \multirow{2}{*}{$B S M \leftrightarrow C S M$} & $17.87 * *$ & 0.0197 & Yes & \multirow[t]{2}{*}{ Bidirectional } \\
\hline & $109.68 * *$ & 0.0014 & Yes & \\
\hline \multirow{2}{*}{$I S M \leftrightarrow P S M$} & 3.802 & 0.1507 & No & \multirow[t]{2}{*}{ None } \\
\hline & 5.194 & 0.1036 & No & \\
\hline \multirow{2}{*}{$I S M \leftrightarrow C S M$} & 1.948 & 0.3052 & No & \multirow[t]{2}{*}{ Unidirectional } \\
\hline & $28.19 * *$ & 0.0103 & Yes & \\
\hline \multirow{2}{*}{$P S M \leftrightarrow C S M$} & 3.684 & 0.1563 & No & \multirow[t]{2}{*}{ Unidirectional } \\
\hline & $64.84 * *$ & 0.0030 & Yes & \\
\hline$B S M \rightarrow A L L$ & $61.31 * *$ & 0.0030 & Yes & Multidirectional \\
\hline$I S M \rightarrow A L L$ & $9.208 * *$ & 0.0466 & Yes & Multidirectional \\
\hline$P S M \rightarrow A L L$ & 5.424 & 0.0950 & No & None \\
\hline
\end{tabular}




\begin{tabular}{|l|l|l|l|l|}
\hline $\boldsymbol{C S} \boldsymbol{M} \rightarrow \boldsymbol{A L L}$ & $68.70^{* *}$ & 0.0025 & Yes & Multidirectional \\
\hline
\end{tabular}

Note: $* *$ denotes rejection of the $\mathrm{H}_{0}$ at $5 \%$ level of significance

NS: Non-significant

$\rightarrow \leftarrow$ means forward and backward directions respectively

\subsection{Effect of Bad-news on the Future Prices of Sesame}

Therelative strength of causality effects beyond the selectedtime span cannot be determined by Granger causality test. In such circumstances, causality test isinappropriate because this test cannot indicatehow much feedback exists from one variable to theother beyond the selected sample period (Rahman and Shahbaz, 2013). The best way to interpret theimplications of the model for patterns of pricetransmission, causality and adjustment are to considerthe time paths of prices after exogenous shocks i.e. impulse responses (Vavra and Goodwin, 2005).

If there is cointegration, the estimation of impulse response function (IRF) is inconsistent at long horizon using the unrestricted VAR, so the stable impulse response function was estimated from the restricted VAR. The integration of order one variables modeled in a cointegrating VECM are not mean reverting, and the unit moduli in the companion matrix imply that the effect of some bad-news will not die-out over time. The IRF results diagrammatically depicted in Figure 1revealed how and to what extent an innovation (bad-news) in one market affects the current and future prices in all the integrated markets in the region over a time span of 10 years.

The graph indicated that unexpected shocks that are local to Bangladesh and Pakistan sesame prices would have transitory effects on the sesame prices of their respective own markets and that of India and China, while bad-news that are local to India and China markets would not die-out overtime in their respective markets, against each other's market and Bangladesh market, but will die-out overtime in Pakistan market.

Having confirmed that the speeds as well as magnitude of shocks given to Bangladesh andPakistan markets are relatively less transmitted toother markets, it can be inferred that these marketsare trend followers and not trendsetters and the reason for their subservient role could be attributed to their new emergence in the global importing sesame seeds market. In addition, they would not play a significant role in the sesame exporting economies of southAsia.

A positive standard deviationshock in the sesame prices would force the consumersto shift from low-quality sesame product to high-quality sesame, thus the hike in low-quality prices would be relatively less reflected inthe Bangladesh and Pakistan markets. Therefore, qualityimprovement of sesame product will have meaningfulimplication that would be reflected in the Bangladesh and Pakistan markets. However, the reason for comparative competency of India market among the sesame exporting economies may be due to its long-time trade in sesame product in the international sesame market and highquality product standard. 

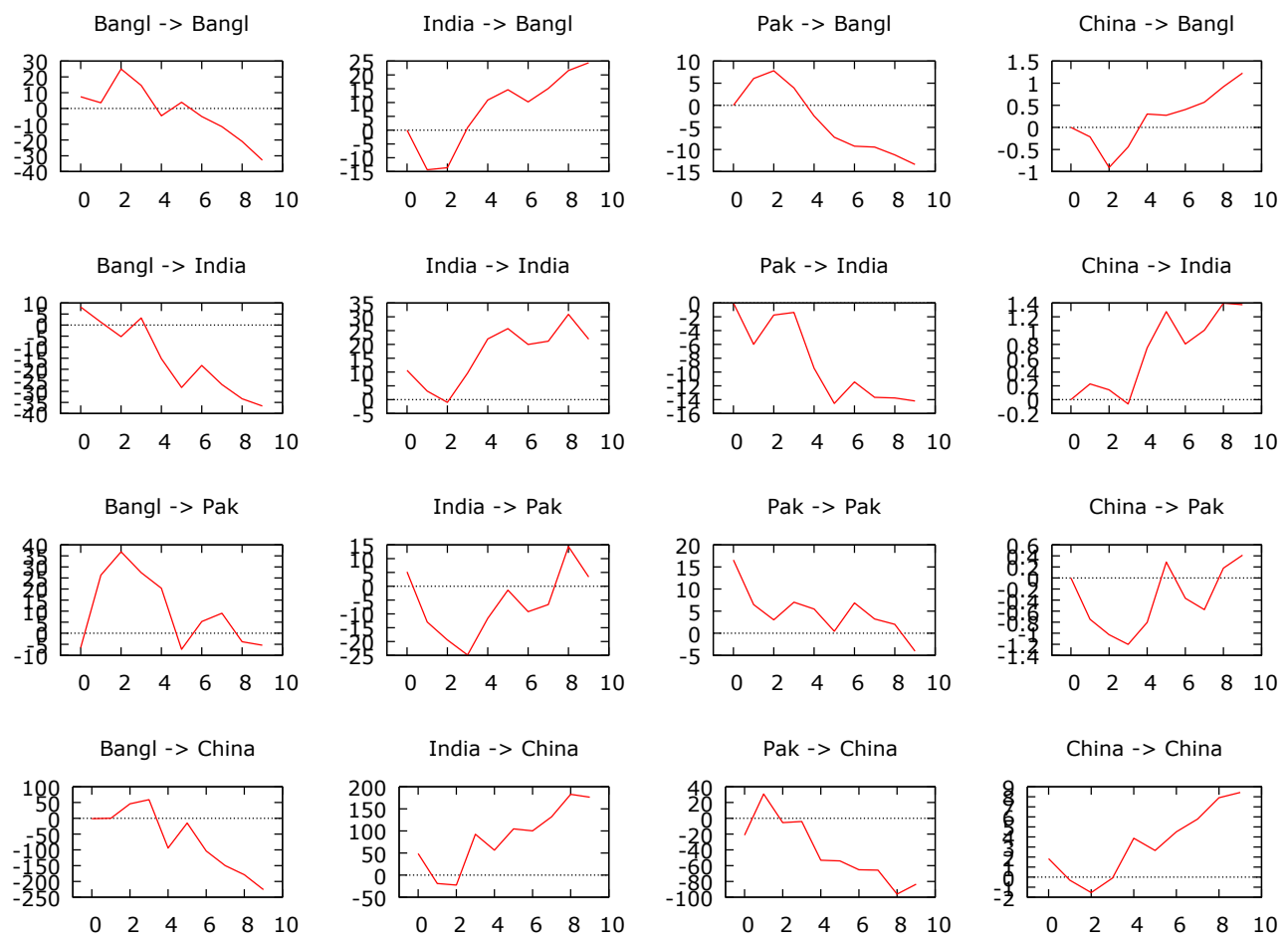

Figure 1. Impulse response of sesame markets to shocks

\subsection{Price Forecast of Sesame}

\section{Diagnostic checking and validation}

The VECM was found to be the appropriate in forecasting theproducer's prices of the selected markets as indicated by the diagnostic test results which exonerated the disturbance variables from the problem of autocorrelation and auto-covariance as evidenced by the LjungBox Q-stats and Langrage multiplier tests respectively which were not different from zero at $10 \%$ risk level (Table 5). Therefore, the absence of random error means that the producer's price of sesameis predictable, and it will be good for policy making, consumer decision and consumption pattern.

\section{Validation (Ex-post prediction power)}

Though price movement prediction is in contrast to the efficient marketing theory which postulated that for a market to operate efficiently, prices should be unpredictable, in that if they are stationary and predictable they will attract investors and their active participation will ultimately lead to the cancellation of the prediction. However, this deductive (theory) idea has little empirical extent as inductive (facts) knowledge showed that prediction of prices is very important in measuring market efficiency except that the prediction should not be too long.

One-step-ahead forecast of the prices along with their corresponding standard errors using naïve approach for the period 2011 to 2015 (total 5 data points) in respect of the VECM fitted model was computed to determine the predictive power of the estimated equation (Table 7a). This was done to examine how closely they could track the path of the actual observation. 
Table 7a. One step ahead forecast of prices

\begin{tabular}{|l|l|l|l|l|l|l|l|l|}
\hline \multirow{2}{*}{ Period } & \multicolumn{3}{l}{ BSM } & \multicolumn{2}{l|}{ ISM } & PSM & \multicolumn{2}{l|}{ CSM } \\
\cline { 2 - 9 } & Actual & Forecast & Actual & Forecast & Actual & Forecast & Actual & Forecast \\
\hline 2011 & 544.4 & 543.2 & 782.1 & 786.6 & 714.4 & 714.2 & 1764.3 & 1795.1 \\
\hline 2012 & 556.7 & 556.1 & 660.1 & 663 & 659.7 & 653.6 & 2122.8 & 2150.4 \\
\hline 2013 & 574.8 & 574.7 & 682.4 & 680.8 & 675 & 673.3 & 2388.7 & 2382.7 \\
\hline 2014 & 617.1 & 615.3 & 696.9 & 691 & 716.1 & 724.6 & 2405 & 2376.9 \\
\hline 2015 & 633.7 & 640.6 & 689.3 & 684.3 & 705.3 & 709.7 & 2412.9 & 2333.3 \\
\hline
\end{tabular}

The price forecasting ability of the producers' market prices of sesame was measured using themean absolute prediction error (MAPE), root mean square error (RMSE), Theil's inequality coefficient (U) and the relative mean absolute prediction error (RMAPE) (Table $7 b$ ). The results indicated the accuracy of the forecasted price as shown by the respective market RMAPE and $U$ which were less than $10 \%$ and less than 1 respectively. Therefore, these relatively low values indicate the consistency of the forecasted prices with the actual prices.

Table 7b. Validation of models

\begin{tabular}{|l|l|l|l|l|l|}
\hline Market & $\mathbf{R}^{\mathbf{2}}$ & MAPE & RMSPE & RMAPE (\%) & Theil's U \\
\hline BSM & 0.999 & 0.88 & 0.016209 & 0.1344 & 0.0177 \\
\hline ISM & 0.998 & 1.92 & 0.020542 & 0.273424 & 0.0056 \\
\hline PSM & 0.998 & 1.02 & 0.037806 & 0.12686 & 0.0266 \\
\hline CSM & 0.995 & 17.22 & 0.665638 & 0.683669 & 0.0261 \\
\hline
\end{tabular}

Source: Authors computation, 2018

\subsection{Price Forecast of sesame seed in the selected markets}

Shown in Table 7c and Figure 2 are the computed one step ahead out of the sample forecast of the producer's sesame prices (dollars per ton) spanning from 2016-2025 for the selected markets. The short span prediction was made in order not to affect market efficiency as long prediction will attract investors which will result in the breakdown of the forecasted price.

A cursory review of the results showed that the predicted sesame seed price of Bangladesh would witness steep decline till it reaches an ebb in the year 2021, and thereafter exhibit an oscillating trend with upward and downward swings. The forecasted sesame price of India would exhibit an oscillating trend with the highest price peaking period being 2018 and the lowest ebbing period being 2020. The sesame seed price of Pakistan will witness a steep increasing trend and will peak in the year 2019 and thereafter a steep decline ebbing in the year 2021. Furthermore, the price trend of Pakistan sesame seed will exhibit an oscillating trend with the periods 2022 to 2023 having upward swing, while 2024 to 2025 will witness downward swing. The predicted price of China sesame seeds will exhibit a declining trend till it ebb at the year 2019, thereafter a flatten like trend though there will be slight rise from the year 2020 to 2022 and then slight fall in the year 2023 to 2024, and then a slight rise at the end of the forecasted period. Therefore, it can be inferred that across the markets, prices of sesame seeds in the future will not be fairly remunerative for the producers which may be due to a collusive effect of the oligopolistic intermediaries in the marketing chain of sesame in the region.

Therefore, there is need to strengthen the production and marketing infrastructure to ensure allocative efficiency in the marketing of sesame in the region so that neither the producers nor the middlemen nay the consumers would be better-off nor worse-off. 
Table 7c. Out of sample price forecast for the selected sesame markets (\$ per ton)

\begin{tabular}{|c|c|c|c|c|c|c|}
\hline \multirow[t]{2}{*}{ Year } & \multicolumn{3}{|l|}{ BSM } & \multicolumn{3}{|l|}{ ISM } \\
\hline & Forecast & LCL & UCL & Forecast & LCL & UCL \\
\hline 2016 & 581.50 & 566.90 & 596.00 & 596.90 & 569.70 & 622.20 \\
\hline 2017 & 573.40 & 538.80 & 608.00 & 601.90 & 572.40 & 631.40 \\
\hline 2018 & 558.50 & 491.10 & 625.90 & 643.80 & 612.30 & 675.30 \\
\hline 2019 & 484.20 & 410.50 & 557.80 & 591.30 & 554.00 & 628.70 \\
\hline 2020 & 425.80 & 348.40 & 503.20 & 533.20 & 466.20 & 600.20 \\
\hline 2021 & 407.30 & 323.20 & 491.40 & 545.20 & 440.80 & 649.70 \\
\hline 2022 & 451.00 & 362.10 & 539.90 & 583.80 & 464.60 & 703.10 \\
\hline 2023 & 452.50 & 354.40 & 550.70 & 615.10 & 475.60 & 754.60 \\
\hline 2024 & 415.00 & 298.40 & 531.50 & 565.10 & 397.40 & 732.90 \\
\hline 2025 & 422.60 & 278.70 & 566.40 & 595.40 & 405.90 & 784.90 \\
\hline \multirow[t]{2}{*}{ Year } & \multicolumn{3}{|l|}{ PSM } & \multicolumn{3}{|l|}{ CSM } \\
\hline & Forecast & LCL & UCL & Forecast & LCL & UCL \\
\hline 2016 & 448.70 & 412.30 & 485.10 & 2102.70 & 1998.50 & 2206.90 \\
\hline 2017 & 382.80 & 313.60 & 452.00 & 1800.70 & 1674.70 & 1926.70 \\
\hline 2018 & 510.10 & 402.90 & 617.30 & 1924.60 & 1763.20 & 2086.00 \\
\hline 2019 & 630.20 & 500.00 & 760.40 & 1312.90 & 1043.90 & 1581.80 \\
\hline 2020 & 589.10 & 450.60 & 727.60 & 1441.80 & 1081.90 & 1801.80 \\
\hline 2021 & 529.20 & 389.90 & 668.40 & 1447.50 & 1018.90 & 1876.10 \\
\hline 2022 & 544.80 & 403.40 & 686.30 & 1494.30 & 965.40 & 2023.20 \\
\hline 2023 & 595.70 & 452.40 & 739.00 & 1418.40 & 747.70 & 2089.00 \\
\hline 2024 & 485.80 & 339.50 & 632.10 & 1297.40 & 439.20 & 2155.60 \\
\hline 2025 & 478.20 & 331.20 & 625.20 & 1334.10 & 295.20 & 2372.90 \\
\hline
\end{tabular}

\subsection{Price Volatility of Sesame seeds}

The price series of all the selected markets met the pre-condition for volatility test as their respective residuals showed presences of cluster volatility and Arch effects. A cursory review of the results showed that persistence volatility existed in the prices of all the selected sesame markets as indicated by their respective estimated sum of the ARCH and GARCH terms which were close to "one" (Table 8). The implication is that the volatility of sesame prices in each of the selected markets has the tendency to persist for a while but will not meander away from the mean value. The perusal of the Table showed that the current volatility in the Bangladesh market and the importing (China) economy was triggered by information about previous price arbitrage of sesame seeds in their respective markets. However, it was observed that the family shock had no effect on current price volatility of sesame seeds in India and Pakistan markets, implying the possibility of outside shocks been responsible for the current volatility in these markets. Based on these outcomes, it is vividly clear that sesame trade is useful and the reason may be attributed to high industrial demand for the product by the importing countries in the global sesame seed markets.

The autocorrelation tests showed that the residuals of the models were none correlated as indicated by their respective Q-stats which were not different from zero at $10 \%$ degree of freedom. However, with the exception of the volatility model for Indian sesame seed price all 
the residuals of the selected price series were not normally skewed as indicated by their respective $\mathrm{Chi}^{2}$ which were different from zero at $10 \%$ risk level. Though, non-normality is not considered a serious problem as data in most cases are not normally skewed.

Table 8. Price volatility of sesame seeds in the selected markets

\begin{tabular}{|c|c|c|c|c|}
\hline Items & BSM & ISM & PSM & CSM \\
\hline \multicolumn{5}{|c|}{ Mean equation } \\
\hline Arch Eff. & $13.058\{0.0003\}^{* * *}$ & $4.762\{0.0290\}^{* *}$ & $4.239\{0.013\}^{* *}$ & $6.838\{0.0089\} * * *$ \\
\hline \multicolumn{5}{|c|}{ Variance equation } \\
\hline Alpha (1) & $0.964(0.257)[3.73]^{* * *}$ & $0.884(14.2)[0.06]^{\mathrm{NS}}$ & $0.500(2.57)[0.194]^{\mathrm{NS}}$ & $0.10(0.044)[2.25]^{* *}$ \\
\hline Beta (1) & $1.0 \mathrm{e}-11(0.24)[4.2 \mathrm{e}-11]^{\mathrm{NS}}$ & $1.197(18.5)[6.4 \mathrm{e}-12]^{\mathrm{NS}}$ & $3.5 \mathrm{e}-11(4.06)[8.7 \mathrm{e}-12]^{\mathrm{NS}}$ & $5.0 \mathrm{e}-11(0.35)[1.4 \mathrm{e}-10]^{\mathrm{NS}}$ \\
\hline$\alpha+\beta$ & 0.96 & 0.88 & 0.50 & 0.10 \\
\hline GARCH fit & 1,1 & 1,1 & 1,1 & 1,1 \\
\hline Normality & $9.56\{0.008\}^{* * *}$ & $3.20\{0.201\}^{\mathrm{NS}}$ & $6.39\{0.0408\} * *$ & $15.5\{0.0004\}^{* * *}$ \\
\hline Autocor. & $0.286\{0.59\}^{\mathrm{NS}}$ & $1.277\{0.53\}^{\mathrm{NS}}$ & $1.821\{0.61\}^{\mathrm{NS}}$ & $2.59\{0.63\}^{\mathrm{NS}}$ \\
\hline
\end{tabular}

\section{CONCLUSION AND RECOMMENDATION}

The empirical evidence showed that the LOP hold between the markets inspite of their spatiality, and the traders in almost all the selected markets respond to price bad-news to maintain an equilibrium values. In addition, a positive standard deviation shock on the lowquality sesame prices of Bangladesh and Pakistan would force buyers to shift toIndian sesame product of high-quality. However, findings showed the trade of sesame seeds to be useful due to high industrial demand for the product by the importing countries in the global sesame seed markets. Therefore, the study recommended that the network of sesame producer's markets should be well-designed in order to maintain an equal distance from each other as it will not only boost direct inter-market competition but will control the massive marketing margins of sesame seeds product. Also, the product can be transported to the deficit importing areas, thus benefiting both the producers and the industrial consumers.

\section{REFERENCES}

ADERETI, F.O. FAPOJUWO, O.E. and ONASANYA, A.S. (2006). Information utilization on cocoa production techniques by farmers in Oluyole Local Government area of Oyo State, Nigeria. European Journal of Social Science 3 (1): 1-7.

AJIBADE, T.B. AYINDE, O.E. ABDOUlAYE, T. and Ayinde, K. (2018). Determinants of Price of Yam in Nigeria: A Times-Series Analysis. Nigerian Journal of Agricultural Economics 8 (1): 109-119

AJIBADE, T.B. AYINDE, O.E. ABDOULAYE, T. and AYINDE, K. (2019) Discovery of Maize Price and Food Crop Market Dynamics in Nigeria. Review of Agricultural and Applied Economics, 22(1): 51-64

ALI, W.O. BETT, H.K. KIPROP, S.K. and KORIR, H. (2014)Economic Analysis of Spatial Integration of Pulse Market in Ethiopia; A case of Selected Pulse Market in Ethiopia. European Journal of Business and Management, 6 (33): 100-108. www.iiste.org

ASOGWA, B. C. EZIHE, J. A. C. and OGEBE, F.O. (2012). Agricultural Marketing Information Usage among Soybean Farmers in Nigeria. International Journal of Innovation and Applied Studies, 1 (2) Pp. 160-170 
BRUNNERMEIER, M.K. (2005). Information leakage and market efficiency. Review of Financial Studies, 18(2): 417-457.

DERCON, S. (1995). On market integration and liberalization: Method and application to Ethiopia. Journal of Development studies 32(1):112-143.

FAN, C.S. \& WEI, X. (2005). The Law of One Price: Evidence from the Transitional Economy of China Review of Economics and Statistics 88 (4):682-697 DOI:10.1162/rest.88.4.682. Source:RePEc

GÓES, C. \& MATHESON, T. (2015). Domestic Market Integration and the Law of One Price in Brazil. IMF Working Paper, Western Hemisphere Department. International Monetary Fund (Working Paper No. 15/213). Retrieved 11 October 2016.

JOHANSEN, S. \& JUSELIUS, K., (1990). Maximum Likelihood Estimation and Inference on Cointegration with Applications to the Demand for Money. Oxford Bulletin of Economics and Statistics, Vol. 52, No. 2, pp. 169-210.

LAMONT, O.A. \& THALER, R.H. (2003). Anomalies: The Law of One Price in Financial Markets. Journal of Economic Perspectives 17 (Fall 2003), pp. 191-202.

MANKIW, N. G. (2011). Principles of Economics (6th ed.). Mason, OH: South-Western Cengage Learning. Page 686.

National Population Commission (2017). Publication of National Population Commission, Abuja, Nigeria

MGBADA, J.U. (2006). Effectiveness of information sources on improved farming practices to women farmers in Enugu State, Nigeria. Global Approaches to Extension Practice, 2 (1): 67-78, 2006.

ORKWOR, G.C., ASIEDU, R. \& EKANAYAKE, I.J. eds (1998). Food Yams: Advances in Research. IITA, Ibadan and NRCRI, Umudike, Nigeria. 249pp

PERSSON, K.G. (2008). Definitions and Explanation of the Law of One Price. eh.net. Economic History Services. Retrieved 6 July 2017.

RAVALLION, M. (1986). Testing Market Integration. American Journal of Agricultural Economics (73):102-109

ROSSI, E. (2010). Impulse Response Functions. Econometrics 10, 1-42 Università di Pavia

STIENEN, J., BRUINSMA, W., \& NEUMAn, F. (2007). How ICT can make a difference in agricultural livelihoods. In Commonwealth ministers reference book (pp.2-4). Retrieved

from http://www.iicd.org/files/ICT\%20and\%20agricultural\%20livelihoods.pdf

STIGLER, G.J. \& SHERWIN, R.A. (1985). The Extent of the Market. Journal of Law and Economics (27):555-585.

ZIVOT, E. and WANG, J. (2006). Vector autoregressive models for multivariate time series. Modeling Financial Time Series with S-Plus ${ }^{\circledR}, 385-429$. 